\title{
SUPPLY CHAIN IN THE MILK MARKET IN THE EU COUNTRIES *
}

\author{
Piotr Borawski ${ }^{1}$, Associate Professor; Marta Guth ${ }^{2}$, PhD, Assistant Professor and James \\ W. Dunn ${ }^{3}$, Emeritus Professor \\ ${ }^{1}$ University of Warmia and Mazury in Olsztyn, Poland; ${ }^{2}$ Poznań University of Economics and Business, Poland; \\ ${ }^{3}$ Pennsylvania State University, the USA
}

\begin{abstract}
The aim of the paper was to present milk supply chain in Poland on the background of the EU in the years 2004-2017. The authors used tabular and descriptive methods to present the changes in the supply chains. We have measured three stages of supply chain of milk: production, wholesale supply and consumption in the years 2013-2017. The survey proved that the biggest wholesale supply of cow's milk in the EU in 2017 was in Germany (31 939 thousand tons), France (24 539), the Netherlands (14 297) and the United Kingdom (15 134).
\end{abstract}

Key words: milk market, supply chains, the EU.

JEL code: Q12, Q11.

\section{Introduction}

The current socio-economic development is largely determined by supply chains and the associated logistics. There are many definitions of supply chains. According to Dyczkowska (2012), "a supply chain is the cooperation between numerous processing, trade and logistic enterprises and enterprises involved in the flow of products, information, and financial resources". As reported by Pietrzak et al. (2010), logistics involves the "management of handling and storage operations that are to enable the flow of products from the places of origin to the places of consumption". It follows from this definition that logistics in the daily sector also concerns the transport of raw material from an agricultural farm to the points of sale. Logistics in agriculture vary depending on the type of products. It follows from this definition that enterprises should cooperate with one another within the supply chain, so that it could operate efficiently. From the perspective of both an enterprise and an agricultural farm, supply logistics play an important role. This process is related to the timely delivery of raw materials. Both an enterprise and an agricultural farm should maintain the purchase stocks at an appropriate level to enable the production process. Supply logistics comprise a cycle of operations associated with the purchase of products or services needed by an enterprise and conforming to the requirements.

The supply chain is of particular importance on the milk market. Milk is a food product that needs to be stored properly. In Poland, milk may be collected in two ways: either collected directly from a farm or delivered to a collection centre, with the first way being particularly preferred by large farms (Falkowski et al., 2008). In dairy farms, milk is stored in low-temperature milk tanks help prevent the development of microorganisms. Most frequently, milk is collected every second day from agricultural farms in tank trucks specially dedicated to this purpose. Then, milk is transported to processing plants where it is processed. The second way of milk collection was important in times of the centrally planned economy. This was the only way for a farmer to deliver milk to a collection centre operated by a dairy enterprise (Falkowski, 2012).

Production logistics involves the flow of information and materials within the entire production process. According to Dyczkowska (2012), the tasks of "production logistics include organisation, control and planning of the flow of raw materials, parts of cooperative elements, and the materials needed by an enterprise". Production logistics is aimed at reducing production costs.

\footnotetext{
* The article was written by the project funded by the National Science Centre allocated on the project OPUS 15 : 2018/29/B/HS4/00392.

1 pboraw@uwm.edu.pl

2 marta.guth@ue.poznan.pl

3 jwd6@psu.edu
} 
The aim of distribution logistics is to coordinate processes at each stage of distribution related to the supply of a final product to a consumer via distribution channels. The longer the distribution channels, the longer the duration of delivery of a final product, and the greater the losses of products. Moreover, longer distribution channels result in greater differences in the prices paid by a consumer and received by an agricultural producer. Distribution logistics involves the delivery of the right product within the right time limits to the right customer. In this process, both the customer service process and the flow of information in both directions are important.

Not only do the changes in organisation of supply chains result in an increase in requirements but also create opportunities for gaining access to new markets and vertically organised supply chain systems. In addition, the liberalisation of Polish trade, and the privatisation of milk processing enterprises have opened the Polish dairy sector to greater foreign competition. These actions have contributed to an increase in investment in the Polish dairy sector (Dries et al., 2009). A study of changes in milk supply chains was conducted by Robinowitz and Liu (2014). Its results show that the processing and retail trade create a need for investments in agricultural farms, and affect the retail price of milk. An analysis of prices of products of agricultural origin within the food chain is a complex issue as agricultural raw materials are, as a rule, processed and differentiated through the process of adjustment to the consumers' requirements (Seremak-Bulge, 2006).

The milk product supply chain refers to the complete chain of values, retail sales, with the consumer as the final link. The milk supply chain comprises primary food production, feed component production, cattle feed production, livestock production and milk production, milk processing, wholesale and retail sales, and consumption (Jarzebowski, 2013).

The objective of the research was to recognize the supply chain in milk markets in Poland and other EU countries in the years 2004-17. The authors address the following questions.

1. What are the wholesale deliveries of cow's milk in EU countries?

2. What is the cow's milk production in the EU countries?

3. What are the indicators of changes in milk supplies to dairies in the European Union countries in 2004-2017?

4. What is the number of dairy cows in the European Union?

The authors used data in the years 2013-2017 and descriptive statistical analysis to describe the changes.

\section{Research results and discussion}

Our initial analysis presents the cow's milk production in the EU countries. As we can see the highest milk production was observed in 2016 in Germany (36 672 thousand tons), France (24 482 thousand tons), the United Kingdom (14 946 thousand tons), the Netherlands (14 324 thousand tons) and Poland (13 253 thousand tons). These countries have a surplus in milk production and must find consumers in other countries (Borawski, Dunn, 2016).

The overproduction of milk production is a problem that was an effect of good conditions and the Common Agricultural Policy. The quota system was introduced in 2003 and it was the incentive for production increases. Another incentive was the direct support payments linked to milk production. Finally, the quota system ended in 2014 and the support prices for butter and milk powder were eliminated. The EU prepared new incentives for the development of milk production, for example: formal conventions between producers and dairy enterprises, creation of multibranch organizations, negotiation of milk prices, and support of cheese production (Guba, Dabrowski, 2012). 
An important factor determining the development of milk production is the number of dairy cows. The number of cows has decreased in the EU. The dairy herd in December 2017 was 23299 thousand head and was $1 \%$ smaller compared to 2016. The decrease of the dairy herd was particularly in the EU-13 because of restructuring processes. The highest decrease of cows numbers in these countries group in December 2017 compared to 2016 was observed in Bulgaria (6,7\%), Croatia (5,4 \%) and Lithuania (4,5\%). The highest increase was in Poland $(1,1 \%)$ and Slovenia $(0,9 \%)$ in the same period. In the same period the reduction of milk cows in the EU-15 was smaller and accounted 0,9\% (number of dairy cows 18193 thousand head). The decrease of cow numbers was particularly seen in such countries as: Holland (7,2 \%), France and Italy (decrease $1 \%$ ) and Germany $(0,4 \%)$. In the same period the increase of dairy cows was seen in Ireland $(3,7 \%)$, Denmark $(1,8 \%)$, Austria $(0,6 \%)$ and Great Britain (0,2 \%). According to the prognosis of European Commission, the decrease of cow number in 2018 will be smaller and will account to 0,4\% (23 million heads). The decrease of cows was offset by the milk yield which increased to 7074 kilograms per cow in 2017 (Milk marketstate and perspectives, 2018). The smaller dairy farms will have problems staying competitive in the milk market. That is why the owners of these farms have to make investments to increase the production and to decrease production costs (Zekalo, 2014).

Milk production is determined by two main factors: cow numbers and milk yield. According to information presented in Table 1, milk production was the highest in 2016 in Germany (32 667 thousand tons), France (24 482), the United Kingdom (14 946), the Netherlands (14 324) and Poland (13 253). These results prove the scope of milk production of the EU. These countries have excess milk and have to find markets for the products in other countries (Borawski and Dunn, 2016; Soczewka and Ginter, 2013).

Milk production increased the most in the years 2013-2016 in Ireland (22,3\%), Germany $(17,1 \%)$ and the Netherlands $(15,4 \%)$. This was the effect of specialization and concentration by dairy farms in the EU countries. The milk production decreased the most in the same period in: Spain $(-30,3 \%)$, Hungary $(-23,9 \%)$, Latvia $(-15,1 \%)$ and Bulgaria $(-11,3 \%)$. According to the European Commission, the milk production in 2017 increased 1,5\% to 165,4 million tons. The increase of milk production was particularly seen in the EU-13 (1,7 \% increase) and a little lower in the EU-15 $(1,4 \%)$. In 2018, according to the milk production forecast in the EU is an increase of $1,2 \%$ to 167,4 million tons. In the same year, the milk yield per cow in the EU will increase to 7192 kilograms. Milk is the primary source of income for dairy farmers. The economic situation of dairy farms is diversified regionally in the EU. According to Smigla (2014), eastern EU countries such as Poland, Bulgaria and Romania achieved weaker economic results, whereas dairy farmers from western EU achieved higher production and better economic results.

Table 2 presents the wholesale supply of cow's milk in the EU in the years 2013-2017. It decreased in Greece $(-5,8 \%)$, Croatia $(-5,4 \%)$, Sweden $(-1,8 \%)$ and Slovakia $(-0,1 \%)$. It increased in the remaining countries of the EU. The biggest wholesale production of cow's milk in 2017 was in Germany (31 939 thousand tons), France (24 539 thousand tons), the United Kingdom (15 134 thousand tons) and the Netherlands (14 297 thousand tons). 
Production of cow's milk in the EU (thousand tons)

\begin{tabular}{|c|c|c|c|c|c|c|c|c|}
\hline \multirow[t]{2}{*}{ Country } & \multicolumn{2}{|c|}{$\begin{array}{c}\text { Production } \\
\text { (Thousand } \\
\text { tons) }\end{array}$} & \multirow[t]{2}{*}{ Median } & \multirow[t]{2}{*}{$\begin{array}{l}\text { Standard } \\
\text { deviation }\end{array}$} & \multirow[t]{2}{*}{$\begin{array}{l}\text { Coefficient } \\
\text { of variation }\end{array}$} & \multirow[t]{2}{*}{ Skewedness } & \multirow[t]{2}{*}{ Kurtosis } & \multirow{2}{*}{$\begin{array}{c}\text { Changes } \\
2013- \\
2016 \\
(\%)\end{array}$} \\
\hline & 2013 & 2016 & & & & & & \\
\hline Austria & 3393 & 3628 & 3526.5 & 97.3 & 2.8 & -0.27 & -1.06 & +10.0 \\
\hline Belgium & 3528 & 3882 & 3816.5 & 205.8 & 5.4 & -0.33 & -1.21 & +8.5 \\
\hline Bulgaria & 1149 & 1019 & 1121.5 & 71.9 & 6.4 & -0.37 & -1.29 & -11.3 \\
\hline Cyprus & 163 & 165 & 164.0 & 3.8 & 2.3 & 0.95 & -0.85 & +1.2 \\
\hline Croatia & 588 & 671 & 640.5 & 51.7 & 8.1 & 0.05 & -1.71 & +14.1 \\
\hline $\begin{array}{l}\text { Czech } \\
\text { Republic }\end{array}$ & 2849 & 3065 & 2963.0 & 107.4 & 3.6 & -0.03 & -1.87 & +7.6 \\
\hline Denmark & 5082 & 5355 & 5245.5 & 128.3 & 0.0 & -0.19 & -1.67 & +5.0 \\
\hline Estonia & 772 & 783 & 788.5 & 20.6 & 2.6 & 0.54 & -1.09 & +1.4 \\
\hline Finland & 2328 & 2400 & 2399.5 & 45.9 & 1.9 & -0.58 & -0.92 & +3.1 \\
\hline France & 24426 & 24482 & 25087 & 737.7 & 2.9 & 0.05 & -1.91 & +0.2 \\
\hline Germany & 31324 & 36672 & 32667 & 2322.7 & 7.0 & 0.87 & -0.84 & +17.1 \\
\hline Greece & 731 & 775 & 746 & 35.8 & 4.8 & -0.41 & -1.33 & +6.0 \\
\hline Hungary & 1773 & 1349 & 1832.5 & 274.1 & 15.7 & -0.89 & -0.88 & -23.9 \\
\hline Ireland & 5601 & 1624 & 6215 & 595.6 & 9.5 & 0.01 & -1.78 & +22.3 \\
\hline Italy & 11281 & 10773 & 11190 & 456.2 & 4.1 & 0.44 & -1.05 & -4.5 \\
\hline Latvia & 912 & 774 & 942.0 & 99.8 & 10.9 & -0.75 & -1.02 & -15.1 \\
\hline Lithuania & 1720 & 1624 & 1757 & 95.3 & 5.3 & -0.33 & -1.31 & -5.6 \\
\hline Netherlands & 12408 & 14324 & 13097 & 871.0 & 6.6 & 0.34 & -1.46 & +15.4 \\
\hline Poland & 12718 & 13253 & 13293 & 358.5 & 2.7 & -0.69 & -0.92 & +4.2 \\
\hline Portugal & 1848 & 1959 & 1948.5 & 91.2 & 4.7 & 0.19 & -1.03 & +6.0 \\
\hline Romania & 3966 & 3954 & 3960 & 309.2 & 7.6 & 0.87 & -0.83 & -0.3 \\
\hline Slovakia & 934 & 957 & 953 & 10.3 & 1.1 & -1.04 & -0.74 & +2.5 \\
\hline Slovenia & 596 & 653 & 627.5 & 26.2 & 4.2 & -0.12 & -1.64 & +9.6 \\
\hline Spain & 6559 & 4569 & 6515.5 & 1054.1 & 17.2 & -1.04 & -0.74 & -30.3 \\
\hline Sweden & 2870 & 2862 & 2902 & 39.4 & 1.4 & -0.02 & -1.97 & -0.3 \\
\hline $\begin{array}{l}\text { United } \\
\text { Kingdom }\end{array}$ & 13943 & 14946 & 15026 & 650.3 & 4.4 & -0.76 & -0.89 & +7.2 \\
\hline
\end{tabular}

Source: authors' calculations based on Milk market. State and perspectives 2017 
Wholesale supply of cow's milk in the European Union in the years 2013-2017 (thousand tons)

\begin{tabular}{|c|c|c|c|c|c|c|c|c|}
\hline \multirow[t]{2}{*}{ Country } & \multicolumn{2}{|c|}{$\begin{array}{c}\text { Wholesale } \\
\text { supply } \\
\text { (Thousand tons) } \\
\end{array}$} & \multirow[t]{2}{*}{ Median } & \multirow[t]{2}{*}{$\begin{array}{l}\text { Standard } \\
\text { deviation }\end{array}$} & \multirow[t]{2}{*}{$\begin{array}{l}\text { Coefficient } \\
\text { of variation }\end{array}$} & \multirow[t]{2}{*}{ Skewedness } & \multirow[t]{2}{*}{ Kurtosis } & \multirow{2}{*}{$\begin{array}{c}\text { Changes } \\
2013- \\
2017 \\
(\%)\end{array}$} \\
\hline & 2013 & 2017 & & & & & & \\
\hline Austria & 2933 & 3200 & 3091 & 95.94 & 3.11 & -0.41 & -0.54 & 9.1 \\
\hline Belgium & 3474 & 4013 & 3882 & 226.72 & 5.95 & -0.59 & -1.15 & 15.5 \\
\hline Bulgaria & 495 & 592 & 510 & 38.82 & 7.37 & 1.13 & -0.28 & 19.6 \\
\hline Cyprus & 157 & 216 & 164 & 25.93 & 14.47 & 0.58 & -1.40 & 37.6 \\
\hline Croatia & 504 & 477 & 504 & 18.26 & 3.64 & -0.20 & -1.29 & -5.4 \\
\hline $\begin{array}{l}\text { Czech } \\
\text { Republic }\end{array}$ & 2382 & 2979 & 2500 & 260.81 & 9.97 & 0.52 & -1.41 & 15.1 \\
\hline Denmark & 5025 & 5479 & 5278 & 186.02 & 3.54 & -0.07 & -1.45 & 9.0 \\
\hline Estonia & 706 & 727 & 720 & 9.61 & 1.33 & -0.34 & -1.19 & 3.0 \\
\hline Finland & 2287 & 2366 & 2366 & 43.08 & 1.83 & -1.03 & -0.36 & 3.5 \\
\hline France & 24191 & 24539 & 24539 & 553.16 & 2.16 & 0.23 & -1.70 & 1.4 \\
\hline Germany & 30301 & 31939 & 31879 & 709.4 & 2.25 & -1.13 & -0.36 & 5.4 \\
\hline Greece & 652 & 614 & 619 & 16.39 & 2.63 & 1.37 & 0.08 & -5.8 \\
\hline Hungary & 1364 & 1525 & 1525 & 75.59 & 5.08 & -1.02 & -0.52 & 11.8 \\
\hline Ireland & 5581 & 7475 & 6585 & 772.48 & 11.95 & -0.09 & -1.37 & 33.9 \\
\hline Italy & 10397 & 11375 & 10773 & 375.30 & 3.45 & -0.32 & -1.05 & 9.4 \\
\hline Latvia & 736 & 813 & 808 & 33.30 & 4.19 & -1.45 & 0.19 & 10.5 \\
\hline Lithuania & 1339 & 1403 & 1416 & 40.38 & 2.87 & -1.05 & -0.37 & 4.8 \\
\hline Netherlands & 12213 & 14297 & 13331 & 988.08 & 7.41 & -0.03 & -1.71 & 17.1 \\
\hline Poland & 9921 & 11647 & 10869 & 641.73 & 5.93 & -0.20 & -0.90 & 17.4 \\
\hline Portugal & 1777 & 1851 & 1851 & 53.86 & 2.91 & 0.01 & -0.59 & 4.2 \\
\hline Romania & 879 & 1028 & 953 & 59.64 & 6.25 & -0.01 & -1.36 & 17.0 \\
\hline Slovakia & 827 & 826 & 827 & 17.68 & 2.11 & 0.87 & -0.82 & -0.1 \\
\hline Slovenia & 517 & 579 & 554 & 26.86 & 4.87 & -0.20 & -1.54 & 12.0 \\
\hline Spain & 6300 & 7014 & 6720 & 271.89 & 4.06 & -0.41 & -0.93 & 11.3 \\
\hline Sweden & 2868 & 2817 & 2868 & 49.56 & 1.72 & -0.09 & -1.41 & -1.8 \\
\hline $\begin{array}{l}\text { United } \\
\text { Kingdom }\end{array}$ & 13687 & 15134 & 14829 & 611.19 & 4.16 & -0.90 & -0.59 & 10.6 \\
\hline
\end{tabular}

Source: authors' calculations based on Milk market. State and perspectives 2017

The smallest wholesale supply of cow's milk in 2017 was found in Cyprus (216 thousand tons), Croatia (377 thousand tons) and Slovenia (579 thousand tons). The wholesale supply of cow's milk decreased in 2017 compared to 2013 in Croatia (-5,4\%), Sweden $(-1,8 \%)$ and Slovakia $(-0,1 \%)$. It increased in the remaining EU countries. The biggest increase of wholesale supply of cow's milk in the EU in 2017 compared to 2013 was observed in Cyprus (37,6 \%), Ireland (33,9\%) and Bulgaria $(19,6 \%)$. Coefficient of variation describes changes in the wholesale supply of cow's milk in the EU. The biggest coefficient of variation was observed in Cyprus $(14.47 \%)$, Ireland (11.95\%) and the Czech Republic (9.97\%).

Milk production is an important part of the economy because it is profiTable and it employs many farmers and their families (Poczta et al., 2008). Another part of the dairy supply chain is the overall dairy industry. The production of dairy products is diversified in the EU countries. A. Parzonko (2013) recognizes that large differences in the level of dairy development in individual countries of the European Union result primarily from their differing level of economic development. The differences between EU-15 countries and the EU-10 countries accessed in 2004 differ greatly. These differences are even deeper for Bulgaria and Romania who joined in 2007. However, these dependencies did not 
apply to domestic sector leaders who, due to their investments, the implementation of know-how, quality management systems, achieved significantly better results than the average ones.

According to Ihle et al. (2017), the main dairy countries in the EU, based on the annual volume of milk being processed, are Germany and France, where more than 25 million tons of milk are processed each year. More than 10 million tons of milk are processed annually in the United Kingdom, the Netherlands and Italy. Apart from Italy, Spain is the largest dairy producing country in the EU-S (more than 7 million tons). Among EU13 MS, Poland and the Czech Republic have the largest dairy sector (3.5 and 2.5 million tons, respectively). The structure of the processing chain of the EU dairy sector differs substantially between MS and between regions. The dairy processing in EU-N MS is based primarily on large-scale dairy companies that process more than 100,000 tons of milk per year. An exception is Ireland, where large-scale dairies process less than $60 \%$ of the total milk volume. In the EU-S and the EU13 MS, a larger share of milk is processed by medium- or small-scale dairy companies. This structure holds especially in countries such as Bulgaria and Romania, where the sector is dominated by small dairy companies that process less than 50 thousand tons of milk annually.

The dairy industry has an accelerated process of concentrating capital. As a result, the number of milk processing enterprises is decreasing year by year. Large, both cooperative and private dairy companies increase the scale and scope of their commercial offer by purchasing declining, mostly cooperative companies. The concentration ratio of the four largest EU dairy companies increased in the period between 2008 and 2013 from 32 \% to $36 \%$ of the total turnover in the dairy sector. Concentration ratios in dairy product markets differ substantially between Member States. They are the highest in the Scandinavian countries with a single dairy company dominating the market: Arla Foods holds between $40 \%$ and $73 \%$ of the market share for different dairy products in Sweden and Denmark; Valio provides $27 \%$ to 52 \% of the dairy retail value in Finland (Ihle et al 2017; Niemi, Ahlstedt 2008). The International Dairy Federation predicts that the concentration of structures in milk processing will continue in other Member States. According to the expertise of the International Dairy Federation, in 2013, among 27 milk processing companies in the world, which achieved an annual turnover of USD 3 billion, there were as many as 10 companies from the European Union (13 from all of Europe), the largest of which are: French Lactalis and Danone, with annual turnover of 21.2 billion and 15.7 billion dollars respectively, Dutch Friesland Campina (15.1 billion USD), DanishSwedish Arla Foods (13.1 billion USD) and German DMK (6.4 billion USD) (Bulletin of International Dairy Federation 476/2014). EU15 dairy companies, such as Danone, Lactalis, Meggle and Hochland, have invested in the dairy markets of the EU13 MS. Nevertheless, important market shares remain with domestic producers (Vindija, Croatia; Madeta, Czech Republic; Mlekpol, Poland). The domestic dairy processor Mlekpol holds a 12 \% overall market share in the Polish dairy market.

An important process, taking place in the background of changes in the production structure, that enables cost reduction, is to reduce the amount of raw material used to produce final products. This is mainly the result of technological progress and the introduction of micro- and nanofiltration on an increasingly large scale, which allows for more efficient recovery of whey proteins. In addition, according to J. Seremak-Bulge (2005), striving to increase value added significantly increases the turnover of semi-finished products between enterprises dealing in milk processing and packaging of milk products (including milk powder, cheese, cream). It can be assumed that these trends will additionally increase as capital is consolidated and the production structure is simplified in production plants in order to reduce labour consumption and reduce production costs. 
The dynamic development of raw milk production in the world in 1990-2010 also indirectly determined changes in its distribution, which were a response to the changing demand for dairy products. According to Baer-Nawrocka et al. (2012), in relation to 1990, the share of butter in 2010 decreased by 3.4 percentage points, skimmed milk powder by 2.1 percentage points in the use of raw milk as the share of cheeses increased by 1.2 percentage point, and whole milk powder by 1.5 percentage points. The share of fresh products in the distribution of global milk production increased from $74.6 \%$ in 1990 to $77.2 \%$ in 2010 (at the expense of a drop in the share of dairy products from $25.4 \%$ in 1990 to $22.8 \%$ in 2010). In Europe in 2010, fresh products accounted for $66.7 \%$ of the use of raw milk, and fixed products $33.3 \%$, of which up to $17.1 \%$ was used for cheese production, $8.2 \%$ for butter production, $4.7 \%$ for skimmed milk powder and 3.2 \% for whole milk powder. These trends even deepened in 2016 (Figure 1).

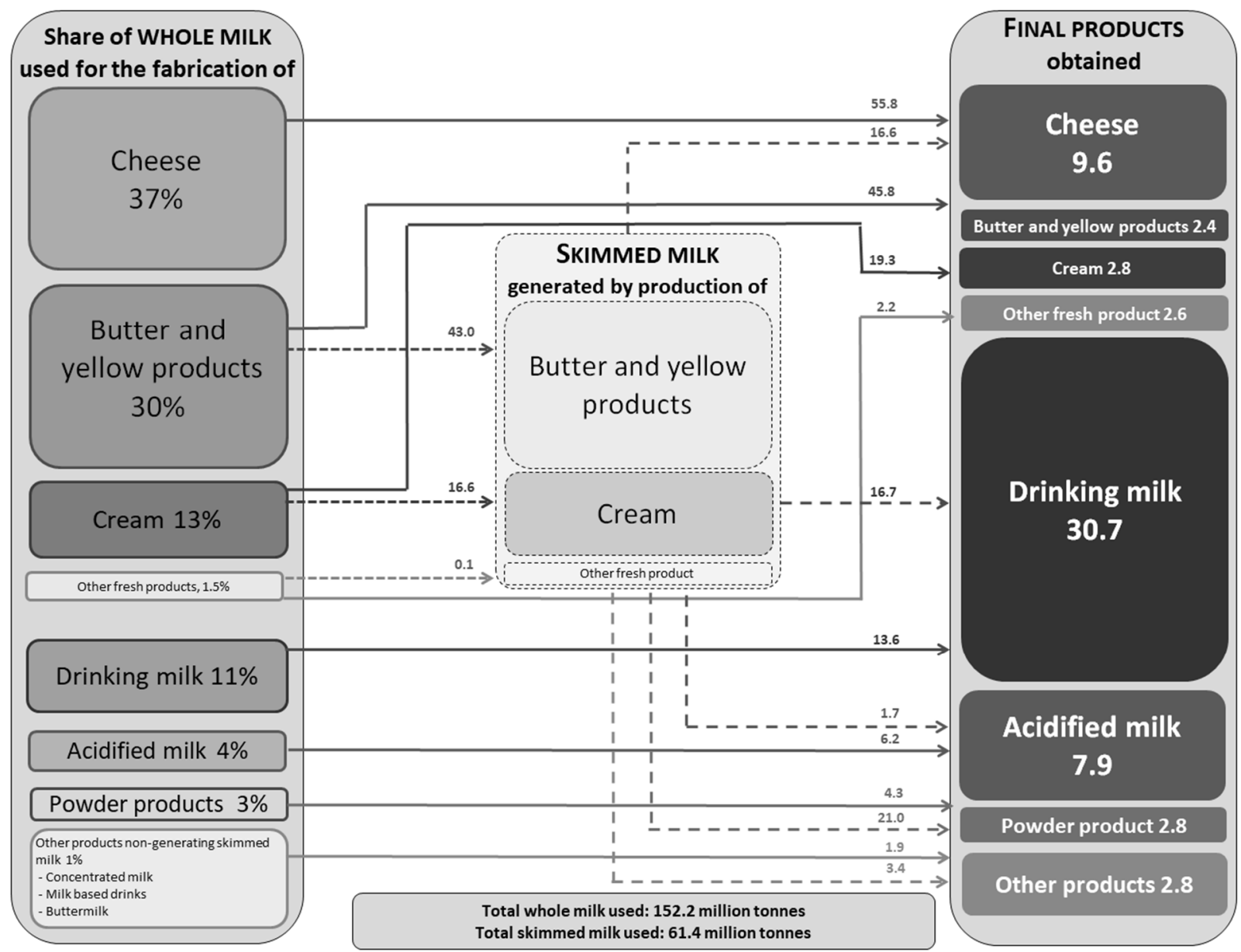

Source: https://ec.europa.eu/eurostat/statistics-

explained/index.php?title=File:Utilisation_of_milk_and_dairy_products_obtained,_EU-28,_2016-Fig.png

Fig. 1. Utilisation of milk and dairy products obtained, EU-28, 2016

The production of butter in the world after a deep decline in the 1990 s (almost $26 \%$, in Europe $24.5 \%$ ) was systematically growing to stabilize between 4.7 and 4.9 million tonnes in the decade 2001-2010. The European Union has over a 41 \% share of global production. The second in the order the United States has only 15 \% share, and the third New Zealand 8 \%. In the European Union, butter production in 2004-2011 decreased slightly, mainly due to low price competitiveness with declining market support. The reform of the Common Agricultural Policy has limited export subsidies, expenditure on intervention purchases and aid for private storage of butter. 


\section{Conclusions, proposals, recommendations}

1) The milk supply chain is a very important part of the agricultural economies of EU countries. The survey proved its development.

2) Most milk in the EU countries is delivered by the biggest producers among which are Germany, France, Great Britain, Holland and Poland. The EU is a big producer of milk and a very important player on world markets.

3) There is a strong process of capital concentration in milk processing.

4) Small milk producers have to improve production and milk yields.

\section{Bibliography}

1. Baer-Nawrocka, A., Grochowska, R., Kiryluk-Dryjska, E., Seremak-Bulge, J., Szajner, p. (2012). Swiatowy rynek mleka i jego wplyw na polskie mleczarstwo po zniesieniu kwot mlecznych (The Global Milk Market and Its Impact on Polish Dairy Industry after the Abolition of Milk Quotas), IERiGZ, Warszawa.

2. Borawski, P., Dunn, J. W. (2016). Zroznicowanie produkcji mleka w krajach UE w aspekcie wspolnej polityki rolnej (Differentiation of milk production in European Union countries in the aspect of common agricultural Policy). Roczniki Naukowe SERiA, tom XVII, zeszyt 2, 9-15.

3. Dries, L., Germenji, E., Noev N., Swinnen, J. F. M. (2009). Farmers, Vertical Coordination, and the Restructuring of Polish Supply Chains in Central and Eastern Europe. World Development 37(11), 17421758.

4. Dyczkowska, J. (2012). Logistyka zaopatrzenia i produkcji-wpływ na logistykę dystrybucji (Supply and production logistics - impact on distribution logistics). Prace Naukowe Politechniki Warszawskiej z. 84, s. 1928.

5. Falkowski, J. (2012). Dairy Supply Chain Modernisation In Poland: What About Those Not Keeping Pace?, European Review of Agricultural Economics 39(3), 397-415.

6. Falkowski, J., Malak-Rawlikowska, A., Mielczarek-Andrzejewska, D. (2008). Dairy Supply Chain Restructuring and Its Impact on farmer's revenues in Poland. $12^{\text {th }}$ Congress of European Association of Agricultural Economists -EAAE.

7. Guba, W., Dabrowski, J. (2012). Deregulacja rynku mleka w Unii Europejskiej-skutki i zalecenia dla Polski (Deregulation of the milk market in the European Union - effects and recommendations for Poland). Rocz. Nauk Rol., seria G, t. 99, z. 1, 32-42.

8. Ihle, R., et al. (2017). Research for Agri Committee - The EU Cattle Sector: Challenges and Opportunities Milk and Meat Technical Report - February 2017 DOI: 10.2861/85585

9. International Dairy Federation. (2014). Bulletin of the International Dairy Federation 476/2014, The World Dairy Situation 2014

10. Jarzebowski, S. (2013). Analiza łańcucha dostaw produktów mlecznych w kontekście zanieczyszczeń środowiska (Analysis Of The Supply Chain Of Dairy Products In The Context Of Environmental Pollution). Zeszyty Naukowe SGGW w Warszawie. Problemy Rolnictwa Światowego 13(28), 95-103.

11. Niemi, J., Ahlstedt, J. ed. (2008). Finnish Agriculture and Rural Industries 2008, Agrifood Research Finland. Economic Research, Publication 108a

12. Parzonko, A. (2013), Globalne i lokalne uwarunkowania rozwoju produkcji mleka (Global And Local Conditions For The Development Of Milk Production) Wydawnictwo SGGW, Warszawa.

13. Pietrzak, M., Baran, J., Maciejczak, M. (2010). Zakres i rola logistyki w przedsiębiorstwach mleczarskich (The Scope And Role Of Logistics In Dairy Enterprises). Wieś Jutra 1(138), 1-5.

14. Poczta, W., Sadowski, A., Sredzinska, J. (2008). Rola gospodarstw wielkoobszarowych w rolnictwie Unii Europejskiej (The Role Of Large-Scale Farms In The Agriculture Of The European Union). Roczniki Nauk Rolniczych seria G. T. 95, z. 1, 42-56.

15. Rabinowitz, A., N., Liu, Y. (2014). The Impact Of Regulations Change On Retail Pricing: The New York State Milk Price Gouging Law. Agricultural and Resource Economics 43(1), 178-192.

16. Rynek mleka. Stan perspektywy (Milk Market. The State And Perspectives). IERiGZ-PIB 2018, Warsaw.

17. Seremak- Bulge, J. ed. (2005). Rozwoj rynku mleczarskiego i zmiany jego funkcjonowania w latach 19902005 (Development Of The Dairy Market And Changes In Its Functioning In The Years 1990-2005), IERiGż, Warszawa.

18. Seremak-Bulge, J. ed. (2006). Ewolucja rynku zbożowego i jej wpływ na proces transmisji cen (The Evolution Of The Grain Market And Its Impact On The Price Transmission Process), IERiGŻ, Warszawa.

19.Smigla, M. (2014). Zroznicowanie produkcji mleka w regionach Unii Europejskiej w latach 2007-2011 (The Diversification Of Milk Production In The Regions Of The European Union In 2007-2011). Progress in Economic Sciences 1, 99-110.

20.Soczewka, I., Ginter, A. (2013). Handel miedzynarodowy artykulami rolno-spozywczymi w Polsce w latach 2007-2011 (International Trade In Agricultural Products In Poland Within 2007-2011). J. Of Agrib. Rural Devel., 2(28), 225-234.

21.Zekalo, M. (2015). Economic Results Of Milk Production In Organic And Conventional Specialized Dairy Farms In Poland. Athens Journal of Business and Economics, January, 63-71. 